\title{
SPECIES DIVERSITY, DISTRIBUTION AND ABUNDANCE OF FISHES OF SETI GANDAKI RIVER BASIN, POKHARA, NEPAL
}

\author{
Kishor K. Pokhare $1^{1 *}$, Khadga B. Basnet ${ }^{2}$, Trilok C. Majpuria ${ }^{3}$ and Chitra B. Baniya ${ }^{4}$ \\ ${ }^{1}$ Department of Zoology, Prithvi Narayan Campus, Pokhara \\ ${ }^{2,3}$ Central Department of Zoology, Tribhuvan University, Kathmandu \\ ${ }^{4}$ Central Department of Botany, Tribhuvan University, Kathmandu \\ *For correspondence: kishorpokhare182@gmail.com
}

\begin{abstract}
Species diversity with indices, distribution and abundance of fishes of Seti Gandaki River Basin, Pokhara, Nepal are described from five study sites, three along the main channel and two in major tributaries. Fishes were sampled using a cast-net following pass-removal method. Environmental variables were determined following the standard methods. In total, 30 species belonging to five orders, nine families and 24 genera with absolute abundance of 10,659 were recorded. A longitudinal pattern of distribution and species richness from upstream to downstream sites (17 to 21 species) was observed. Cyprinids were dominant followed by silurids, balitorids, channids, mastacembelids, belonids and cobitids. Distribution pattern and abundance data showed that the species Tor tor, Tor putitora, Chaguninus chagunio, Barilius barila, Opsarius barna, Danio rerio, Lepidocephalichthys guntea, Parachiloglanis hodgarti and Amblyceps mangois were not common in the study area. The environmental variables such as depth, width, discharge and temperature showed effect upon species richness, abundance, distribution and diversity indices, which had lower values at upstream pre-urban sites than at downstream post-urban sites. A sharp decline in species richness, abundance and diversity indices at urban site (10 species) indicated urban influence.
\end{abstract}

Key words: Cyprinids, diversity indices, lotic habitat, urban influence.

\section{INTRODUCTION}

Fishes are aquatic fauna serving as food, recreation, biological control agents, animal feed, manure, decoration, sports etc. to human being from the time immemorial. The riverine water resources of Pokhara Valley are habitat of several species of fishes along with many aquatic biodiversity from protozoa to mammals. River, streams and creeks in the region have high water velocity and the aquatic organisms inhabiting these bodies possess structural modifications. The rich fish biodiversity of the lotic waterbodies in the valley is declining due to lack of proper knowledge and/or ignorance of stakeholders such as fisher communities, local people and authorities. The factors accelerating the declination causing destruction of habitat and deterioration of water quality are deforestation in the watershed area; indiscriminate over-fishing; increased use of toxic chemicals like fertilizers and pesticides in the cultivated land, illegal fishing practices such as poisoning and electro-fishing, construction of dam and diversion of river water to canal for irrigation of cultivated land, or electricity generation; and extraction of river-bed substrata such as sand, gravel, pebbles, cobbles, boulders etc. as raw materials for construction works etc. So, freshwater ecologists have suggested 
regular ecological monitoring of water-bodies to reflect the status of aquatic biodiversity (Nikolsky, 1963; Allan, 1995; Dudgeon, 1999, Wu et al., 2011). A longitudinal pattern of spatial variation in species richness and abundance of fishes have been described from various riverine water-bodies (Edds, 1993; Williams et al., 1996) which may decline at sites receiving urban and/ or industrial wastes (Edds et al., 2002).

Studies on fish diversity of Pokhara Valley are those of Ferrow and Badgami (1980), John and Dhewajoo (1989), FRC Pokhara (1991-92), Pokharel (2006), and Gubhaju and Giri (2010). However, midland river and streams in the valley have not been studied thoroughly yet. Seti Gandaki River along with its tributaries running through the middle of the valley constitute important freshwater ecosystem. Considering them as the habitats of aquatic biodiversity including fishes, the objectives of present study is to investigate species diversity with indices, abundance and distribution of fishes in these water-bodies.

\section{MATERIALS AND METHODS}

\section{Study Area}

Pokhara Valley is located between 27050' and $28^{\circ} 10^{\prime}$ N latitude, $83^{\circ} 50^{\prime}$ and $84^{\circ} 50^{\prime}$ E longitude, altitudes from $540 \mathrm{~m}$ to $1020 \mathrm{~m}$ asl and the valley covers nearly $200 \mathrm{~km}^{2}$ (Tripathi 19841985). It extends north-west to south-east for $25 \mathrm{~km}$ and north to south between 8 to $15 \mathrm{~km}$ (Fig.1). The valley has diverse physiographic features with the presence of river, streams, lakes, caves, terraces, deep gorges, and steep slopes bounded by Mahabharat hills and high Himalayan ranges to the north and mid-hills on the east, south and west. The Seti Gandaki River and its tributaries are the main lotic water-bodies of the valley. The river originates near the base of Mount Machhapuchhre (6,997 $\mathrm{m})$ and Mount Annapurna IV (7,525 m), and receives several tributaries as it passes through the middle of the valley forming deep gorges. The river with a total length of nearly $112.6 \mathrm{~km}$ and the catchment area of $600 \mathrm{~km}^{2}$ joins the Trishuli River at Gaighat in Tanahun District (Sharma 1977). The major tributaries are the Mardi and the Vijaypur. The Mardi, a snow-fed stream, originates from the Mardi Himal $(5,127$ m) and runs about $25 \mathrm{~km}$ before joining the Seti Gandaki River near Lahachok, 12 km from Pokhara. The Vijaypur, a spring-fed stream, arises at the foot of the Mahabharat hills in the north-eastern side of the valley and is nearly 15 $\mathrm{km}$ in length. It runs through the eastern part of the valley and joins the Seti Gandaki River, 13 $\mathrm{km}$ from the Pokhara city. These water-bodies form typical Himalayan lotic ecosystems having unique physio-hydrological features such as, high velocity, low to moderate temperature and unstable river-bed substrata. Five study sites A to E (1 to 5), (Fig. 1), including upstream pre-urban sites (not effected by urban influence) urban site (effected by urban influence), and downstream post-urban Sites (with improvement in effects of urban influence), were selected from the Seti Gandaki River, the Mardi and the Vijaypur streams based on accessibility and less disturbed by human activities.

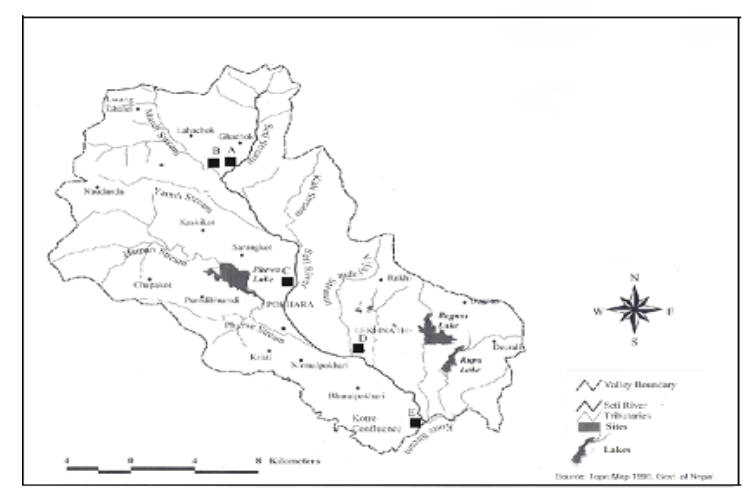

Figure 1: Study area in the Pokhara Valley.

Site A (in main channel) and Site B (in the Mardi stream), $11.12 \mathrm{~km}$ each from the urban site, 
were upstream sites, and had patchy forests, rural settlements and cultivated land in their catchment. Site C (in main channel) was the urban site, $2 \mathrm{~km}$ east of Pokhara city center with urban settlements and cultivated land in the catchment. Site D (in the Vijaypur stream) was $8.46 \mathrm{~km}$ downstream from the urban site, had cultivated land, poultry farms and settlement areas in the catchment. Site E (in the main channel) was the downstream site,15.39 $\mathrm{km}$ from urban site, had settlement areas and cultivated land in the catchment. The river-bed showed less sand and gravel but more cobbles and boulders in the upstream sites than in the urban and downstream sites.

\section{Sampling}

Fishes were sampled using a cast-net $(433 \mathrm{~cm}$ in diameter, $252 \mathrm{~cm}$ in length and $6 \mathrm{~mm}$ mesh size) thrown by a fisherman following Ricker (1968) and APHA (1998). For estimation of abundance, a two-pass removal method (Seber and Lecren, 1967) was used. Each removal pass included moving upstream and then downstream within a predetermined area of 0.1ha. It was done carefully, to assess the fish diversity including depletion and data tabulated as sum of all catches. The surface area of the river section was calculated by using width and length of the predetermined area. Sampling was performed with equal effort (30 minutes) for each pass at each site. Fishes were caught, examined, counted, identified and released unharmed into the water. Fish samples requiring taxonomic verification were collected, preserved in $10 \%$ formalin and voucher specimens were deposited in the laboratory of department of Zoology, Prithvi Narayan Campus, T.U., Pokhara. Fishes were identified following Day (1878), Shrestha (1981), Jayram (1999), and Shrestha (2008). The abundance of fishes was expressed as number per 0.1 ha.
Physio-hydrological variables were measured/ recorded fortnightly and the data were pooled and tabulated as monthly observations following standard methods of Golterman et al. (1978), Trivedy and Goel (1984), Das (1989), and APHA (1998).

\section{Data Analysis}

The Diversity Index $\left(\mathrm{H}^{\prime}\right)$ of fishes was determined using the Shannon-Weiner Equation (Shannon and Weiner, 1963; Pileou, 1977; and Sugihara, 1980):

$H^{\prime}=-\sum_{i=1}^{s}\left(\frac{n i}{N}\right) \log 2\left(\frac{n i}{N}\right)$

Where, $\mathrm{H}^{\prime}=$ Shannon-Weiner Diversity Index, $\mathrm{ni}=$ total number of individuals of a species and $\mathrm{N}=$ total number of individuals all species.

Equitability or evenness ( $\left.J^{\prime}\right)$ of the fish community structure was calculated using the Pielou's Index formula (Pielou, 1975,1977):

$\mathrm{J}^{\prime}=\mathrm{H}^{\prime} / \log \mathrm{s}$

where, J'= Equitability or evenness measure, $\mathrm{H}^{\prime}=$ Shannon-Weiner value and $\mathrm{s}=$ total number of species sampled.

The Concentration of Dominance $(\mathrm{C})$ or the Simpson Index was determined using the Simpson Index formula (Simpson, 1943):

$C=\sum_{i=1}^{s}\left(\frac{n i}{N}\right) 2$

where, $C=$ concentration of Dominance or Simpson Index, ni= total number of individuals of a species and $\mathrm{N}=$ total number of individuals of all species.

Species Distribution Modeling (SDM) was performed to determine pattern of fish species abundance with respect to physic-hydrological variables of each studied site as predictors (Hijmans and Elith 2013) and was done in 'R' (R Core Team, 2015). 


\section{RESULTS AND DISCUSSION}

\section{Diversity, distribution and abundance}

A total of 30 fish species belonging to five orders, nine families and 24 genera were recorded from the Seti Gandaki River basin in the Pokhara Valley (Table 1). An absolute abundance of 10,659 individuals of various species, species richness with percentage of the total abundance contributed by each species and at each site are mentioned in the Table 1. Cyprinids with 17 species were dominant, followed by silurids with five species, balitorids with three species, cobitids with one species. Other fishes included two species of channids, and one species of belonid and mastacembelid each. Among cyprinids, cyprinines and rasborines with seven species each, were the dominant subfamilies followed by two species of garrines and one schizothoracine. An increasing trend of species richness from the upstream site (Site A) (17 species) to downstream site (Site E) (21 species) along the main channel with lowest (10 species) at urban site (Site C) was recorded.
In comparison, upstream tributary (Site B) and downstream tributary (Site D) had 19 and 18 species respectively.

Mean abundance values and standard error of various species of fishes are shown in Table 2. It shows that the standard error values \pm 0.01 $\geq$ to 0.09 as found for the species such as, Neolissocheilus hexagonolepis, Tor putitora, Tor tor, Chagunius chagunio, Barilius barila, Danio rerio, Garra gotyla, Turcinoemacheilus himalaya, Schistura rupecula, Lepidocephalichthys guntea, Pseudecheneis eddsi, Parachiloglanis hodgarti, Glyptothorax pectinopterus, Amblyceps mangois, Mystus bleekeri, Xenentodon cancila, Channa orientalis, C. punctata and Mastacembelus armatus, indicate normal distribution among the studied sites, and the values $+0.1>$ as found for the species such as, Puntitus sophore, Pethia conchonius, Naziritor chelynoides, Barilius bendelisis, B. vagra, Opsarius barna, Danio dangila, Esomus danricus, Garra annandalei, Schizothorax richardsonii and Acanthocobitis botia, indicate some deviation from the mean in distribution among the studied sites.

Table 1: List of fishes, their abundance, species richness and percentage (\%) contribution by each species at sites $\mathrm{A}$ to $\mathrm{E}$ in the Seti Gandaki River basin during 2011-12, no./0.1 ha.

\begin{tabular}{|l|l|l|l|l|l|l|l|}
\hline Taxon & A & B & C & D & E & Total & $\%$ \\
\hline Family: Cyprinidae & & & & & & & \\
\hline Neolissocheilus hexagonolepis (Mc Clelland) & 70 & 69 & 62 & 65 & 94 & 360 & 3.37 \\
\hline Puntius sophore (Hamilton-Buchanan) & 222 & 111 & 117 & 167 & 151 & 768 & 7.20 \\
\hline Pethia conchonius (Hamilton-Buchanan) & 337 & 158 & 164 & 202 & 205 & 1066 & 10.00 \\
\hline Tor putitora (Hamilton-Buchanan) & - & - & - & 32 & 38 & 70 & 0.65 \\
\hline Tor tor (Hamilton-Buchanan) & - & - & - & - & 24 & 24 & 0.22 \\
\hline Naziritor chelynoides (Mc Clelland) & 140 & 201 & - & - & - & 341 & 3.19 \\
\hline Chagunius chagunio (Hamilton-Buchanan) & - & - & - & - & 61 & 61 & 0.57 \\
\hline Barilius bendelisis (Hamilton-Buchhanan) & 370 & 306 & 214 & 370 & 268 & 1528 & 14.33 \\
\hline B. vagra (Hamilton-Buchanan) & 73 & 119 & - & 260 & 118 & 570 & 5.34 \\
\hline B. barila (Hamilton-Buchanan) & - & - & - & - & 54 & 54 & 0.50 \\
\hline Opsarius barna (Hamilton-Buchanan) & - & - & - & - & 31 & 31 & 0.29 \\
\hline
\end{tabular}




\begin{tabular}{|c|c|c|c|c|c|c|c|}
\hline Danio rerio (Hamilton-Buchanan) & - & - & - & - & 92 & 92 & 0.86 \\
\hline D. dangila (Hamilton-Buchanan) & - & - & - & 207 & - & 207 & 1.94 \\
\hline Esomus danricus (Hamilton-Buchanan) & - & - & - & 164 & - & 164 & 1.53 \\
\hline Garra annandalei (Hora) & 328 & 359 & - & 166 & 61 & 914 & 8.57 \\
\hline G. gotyla (Gray) & 130 & 113 & 126 & 73 & 190 & 632 & 5.92 \\
\hline Schizothorax richardsonii (Gray) & 228 & 180 & 72 & 46 & 44 & 570 & 5.34 \\
\hline \multicolumn{8}{|l|}{ Family: Balitoridae } \\
\hline Acanthocobitis botia (Hamilton-Buchanan) & - & - & 113 & 219 & 91 & 423 & 3.96 \\
\hline $\begin{array}{l}\text { Turcinoemacheilus himalaya (Conway, Edds, } \\
\text { Shrestha and Mayden) }\end{array}$ & 59 & 59 & - & 56 & 42 & 216 & 2.02 \\
\hline Schistura rupecula (Mc Clelland) & 49 & 110 & - & - & - & 159 & 1.49 \\
\hline \multicolumn{8}{|l|}{ Family: Cobitidae } \\
\hline $\begin{array}{l}\text { Lepidocephalichthys guntea (Hamilton- } \\
\text { Buchanan) }\end{array}$ & - & 45 & - & - & - & 45 & 0.42 \\
\hline \multicolumn{8}{|l|}{ Family: Sisoridae } \\
\hline Pseudecheneis eddsi (Ng) & 115 & 114 & - & - & - & 229 & 2.14 \\
\hline Parachiloglanis hodgarti (Hora) & 30 & 49 & - & - & - & 79 & 0.74 \\
\hline Glyptothorax pectinopterus (Mc Clelland) & 82 & 91 & - & 56 & - & 229 & 2.14 \\
\hline \multicolumn{8}{|l|}{ Family: Amblycipitidae } \\
\hline Amblyceps mangois (Hamilton-Buchanan) & 19 & 36 & - & - & - & 55 & 0.51 \\
\hline \multicolumn{8}{|l|}{ Family: Bagridae } \\
\hline Mystus bleekeri (Day) & - & - & - & - & 103 & 103 & 0.96 \\
\hline \multicolumn{8}{|l|}{ Family: Belonidae } \\
\hline Xenentodon cancila (Hamilton-Buchanan) & - & - & - & 128 & 105 & 233 & 2.18 \\
\hline \multicolumn{8}{|l|}{ Family: Channidae } \\
\hline Channa orientalis (Bloch and Schneider) & 114 & 120 & 130 & 92 & 115 & 571 & 5.35 \\
\hline C. punctata (Bloch) & - & 92 & 103 & 69 & 79 & 343 & 3.21 \\
\hline \multicolumn{8}{|l|}{ Family: Mastacembelidae } \\
\hline Mastacembelus armatus (Lacepede) & 97 & 123 & 104 & 91 & 107 & 522 & 4.89 \\
\hline Total: & 2463 & 2455 & 1205 & 2463 & 2073 & 10659 & 100 \\
\hline Species richness: & 17 & 19 & 10 & 18 & 21 & - & - \\
\hline
\end{tabular}

The mean values of environmental variables included in the study at each site with standard deviation are presented in Table 3. Complex physio-hydrological features such as depth, width, velocity, discharge, conductivity, transparency, turbidity and temperature influenced the species composition, abundance and distribution of fishes in the present study. Dhanze et al. (1998), and Braaten and Guy (1999) reported water temperature and water velocity as factors influencing species composition and abundance of fishes in the Beas Drainage 
system, North-Western India and in the Lower Missouri River, USA. Fialho et al. (2008), Shrestha et al. (2009), Dubey et al. (2012) and Gupta et al. (2012) observed water temperature and conductivity as factors which influence the fish assemblage structure in the Meia Ponte River, Upper Parana basin, Central Brazil; in the Tamor River, Eastern Nepal; in the Ganges River basin, Central India; and in the Gomti River, a tributary of the Ganges River basin, Northern India. Esselman and Allan (2010) and Pease et al. (2012) mentioned stream depth and width as influencing factors in rivers of NorthEastern Mesoamerica and in the Rio Grijalva basin, Southern Mexico. Edds (1993) and Li et al. (2012) observed stream depth, width and current velocity as factors influencing the fish assemblages in the Gandaki River, Nepal and in the North Tiaoxi River, China.

Lower species richness at the upstream site (Site A) of the main channel could be due to lower water temperature (snow-fed nature), depth, width and discharge, and in urban site (Site C) could be due to urban waste discharge that altered abiotic and biotic characteristics; but higher richness at the downstream site (Site E) of the main channel due to higher temperature, depth, width and discharge, and improvement in the effect of urban influence in the present study. Edds et al. (2002), Yildrim et al. (2008), and Shukla and Singh (2013) described decline in species richness and abundance of fishes downstream from the point of urban influence in the Narayani river, Nepal; the Upper Coruh river, Turkey; and the Aami river, India, respectively.
Table 2: Mean abundance values and standard error of various fish species in the Seti Gandaki River basin during 2011-2012.

\begin{tabular}{|l|l|}
\hline Taxon & $\begin{array}{l}\text { Mean and } \\
\text { Standard error }\end{array}$ \\
\hline Neolissocheilus hexagonolepis & $4.0 \pm 0.07$ \\
\hline Puntius sophore & $6.6 \pm 0.11$ \\
\hline Pethia conconius & $9.38 \pm 0.16$ \\
\hline Tor putitora & $2.1 \pm 0.04$ \\
\hline Tor tor & $1.2 \pm 0.02$ \\
\hline Naziritor chelynoides & $8.6 \pm 0.14$ \\
\hline Chagunius chagunio & $2.2 \pm 0.04$ \\
\hline Barilius bendelisis & $12.3 \pm 0.21$ \\
\hline B. vagra & $9.5 \pm 0.16$ \\
\hline B. barila & $2.1 \pm 0.04$ \\
\hline Opsarius barna & $1.4 \pm 0.23$ \\
\hline Danio rerio & $3.5 \pm 0.06$ \\
\hline D. dangila & $8.2 \pm 0.14$ \\
\hline Esomus danricus & $6.6 \pm 0.11$ \\
\hline Garra annandalei & $14.8 \pm 0.25$ \\
\hline G. gotyla & $5.7 \pm 0.09$ \\
\hline Schizothorax richardsonii & $8.6 \pm 0.14$ \\
\hline Acanthocobitis botia & $8.0 \pm 0.13$ \\
\hline Turcinoemacheilus Himalaya & $3.02 \pm 0.05$ \\
\hline Schistura rupecula & $4.0 \pm 0.07$ \\
\hline Lepidocephalichthys guntea & $2.01 \pm 0.03$ \\
\hline Pseudecheneis eddsi & $5.5 \pm 0.09$ \\
\hline Parachiloglanis hodgarti & $2.5 \pm 0.04$ \\
\hline Glypthothorax pectinopterus & $4.01 \pm 0.07$ \\
\hline Amblyceps mangois & $1.8 \pm 0.03$ \\
\hline Mystus bleekeri & $3.7 \pm 0.06$ \\
\hline Xenentodon cancila & $5.32 \pm 0.09$ \\
\hline Channa orientalis & $3.9 \pm 0.07$ \\
\hline C. punctata & $4.01 \pm 0.07$ \\
\hline Mastacembelus armatus & \\
\hline
\end{tabular}


Table 3: Mean values and standard deviation of environmental variables at sites A to E of the Seti Gandaki River basin during 2011-12

\begin{tabular}{|l|l|l|l|l|l|l|}
\hline Variable & A & B & C & D & E & $\begin{array}{l}\text { Mean and standard } \\
\text { deviation }\end{array}$ \\
\hline Depth $(\mathrm{m})$ & 0.93 & 0.70 & 1.00 & 0.72 & 1.22 & $0.90 \pm 00.30$ \\
\hline Width $(\mathrm{m})$ & 29.68 & 25.19 & 32.71 & 25.26 & 48.75 & $32.30 \pm 13.00$ \\
\hline Velocity $\left(\mathrm{ms}^{-1}\right)$ & 1.47 & 0.91 & 1.02 & 0.93 & 0.96 & $1.10 \pm 00.30$ \\
\hline Discharge $\left(\mathrm{m}^{3} \mathrm{~s}^{-1}\right)$ & 47.07 & 21.72 & 40.83 & 21.11 & 68.46 & $40.00 \pm 37.00$ \\
\hline Turbidity $(\mathrm{FTU})$ & 82.92 & 60.89 & 95.21 & 79.42 & 88.58 & $81.40 \pm 51.00$ \\
\hline Transparency $(\mathrm{cm})$ & 33.09 & 34.57 & 21.59 & 29.73 & 26.52 & $29.10 \pm 15.00$ \\
\hline Conductivity $(\mu \mathrm{mho})$ & 99.16 & 96.60 & 211.62 & 209.06 & 211.81 & $166.00 \pm 80.00$ \\
\hline Temperature-air $\left({ }^{0} \mathrm{c}\right)$ & 18.11 & 18.71 & 20.12 & 21.14 & 22.38 & $20.00 \pm 05.00$ \\
\hline Temperature-water $\left({ }^{0} \mathrm{c}\right)$ & 16.56 & 16.62 & 17.73 & 18.55 & 18.45 & $18.00 \pm 04.00$ \\
\hline
\end{tabular}

\section{Indices of diversity}

The Shannon-Weiner Diversity Index $\left(\mathrm{H}^{\prime}\right)$ value of fish were lower (2.25) at the urban site (Site C) in comparison to the upstream site (Site A) (2.57) and downstream site (Site E) (2.87) in the main channel, as well as upstream tributary site (Site B) (2.79) and downstream tributary site (Site D) (2.69) as depicted in figure 2. As the species diversity comprises two components, the number of species (species richness) and the distribution of individuals of all species (equitability), communities having similar richness may have different diversity indices depending upon the distribution of individuals among the species. The nearly similar diversity index values at sites $\mathrm{A}$ and $\mathrm{B}$, and $\mathrm{D}$ and $\mathrm{E}$ indicate the similar habitat conditions.

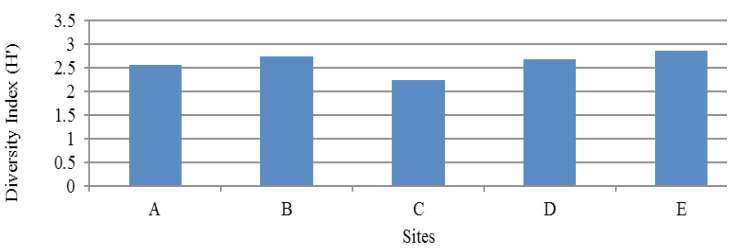

Figure 2: Shannon-Weiner Index $\left(\mathrm{H}^{\prime}\right)$ values at sites A to $\mathrm{E}$.

Equitability or evenness $\left(J^{\prime}\right)$ value of fish were generally lower in the present water-bodies.
It was lower (0.32) at the urban site (Site C) in comparison to upstream site (Site A) (0.33) and downstream site (Site E) (0.38) in the main channel. It was also lower in comparison to upstream tributary Site (Site B) (0.34) and downstream tributary site (Site D) (0.34) as depicted in figure 3 . The values followed those of diversity index values, being higher at tributary sites and downstream main channel site in comparison to upstream and urban sites.

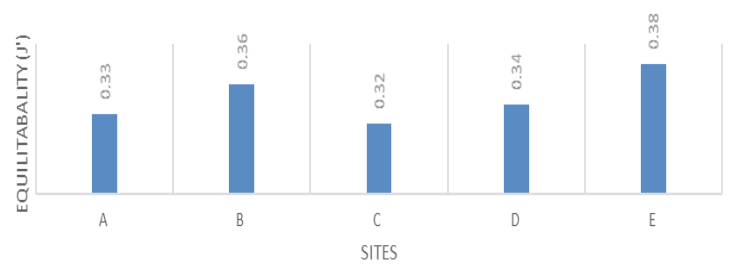

Figure 3: Equitability ( $\left.\mathrm{J}^{\prime}\right)$ values at sites $\mathrm{A}$ to $\mathrm{E}$. The Simpson index or concentration of dominance (C) values of fish were generally higher in the present water-bodies. It was lower $(0.89)$ at the urban site (Site C) in comparison to upstream main channel site (Site A) (0.91) and downstream main channel site (Site E) (0.93), and to upstream tributary site (Site B) (0.93) and downstream tributary site (Site D) (0.92) as depicted in figure 4. 


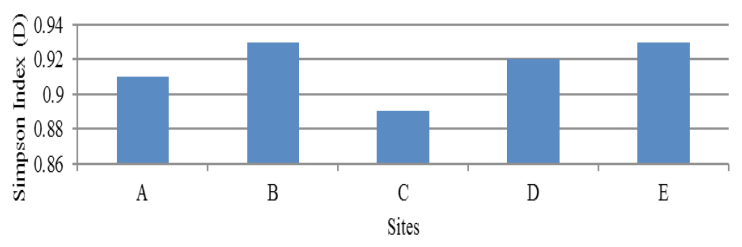

Figure 4: Simpson Index values at sites $\mathrm{A}$ to $\mathrm{E}$.

Generally, moderate species diversity index $\left(\mathrm{H}^{\prime}\right)$ values were observed in the present study, which could be related to the high turbidity, lower transparency reducing photosynthetic activity and productivity, and comparatively higher values at upstream tributary (Site B) and downstream site (Site E) in the main channel to the less effects of human activities, and longitudinal pattern of distribution and abundance. Likewise, lower values of equitability $\left(J^{\prime}\right)$ of fish were observed in the present study, which could be related to human perturbations in the water-bodies. Similar values were mentioned by Brownlow and Bolen (1994), Lasso (2001) and Sumith et al. (2011) in alluvial streams, North Carolina, USA; in the Upper Rio Negro, Bolivian Amazon; and in the Mahaweli river basin, Sri Lanka, respectively. Generally, higher values of the Simpson Index or concentration of dominance (C) were observed in the present study indicating more effect of dominant groups upon others. Similar values were reported by Sumith et al. (2011), and Shukla and Singh (2013) in the Mahaweli River basin, Sri Lanka, and in the Aami river, India.

To conclude, cyprinids had higher density than balitorids, channids, mastacembelids, sisorids, amblycipitids, belonids, cobitids and bagrids at all sites in the present water-bodies. Lower species richness, abundance, distribution and diversity indices at upstream site in the main channel, due to lower values of physicohydrological features such as, temperature, depth, width and discharge; which declined at urban Site due to urban influence, but gradually inclined at downstream sites due to higher values of temperature, depth, width and discharge, as well as improvement in the effect of urban influence.

\section{ACKNOWLEDGEMENTS}

We are grateful to the Dean's Office, Institute of Science and Technology, Tribhuvan University, Kathmandu, Nepal, for approval to conduct the present study, and Mr. R.G. Dhewajoo, Head of the Department of Zoology, Prithvi Narayan Campus (PNC), Pokhara, for providing the laboratory facilities. Thanks are also due to Mr. B.R. Pahari, (Senior Lab Assistant) and Mr. O.L. Jalari (Staff) PNC, for their assistance in the laboratory and field works.

\section{REFERENCES}

Allan, J.D. (1995). Stream Ecology: Structure and Function of Running Waters. Kluwer Academic Publishers, Dordrech, the Netherlands.

APHA/AWWA/WEF (1998). Standard Methods for the Examination of Water and Wastewater. 20 ${ }^{\text {th }}$ edition. American Public Health Association (APHA), American Water Works Association (AWWA) and Water Environment Federation (WEF).

Braaten, P. J. and C.S. Guy (1999). Relations between physicochemical factors and abudance of fishes in tributary confluences of the lower channelized Missouri River. Transactions of the American Fisheries Society, 128 (6):1213-1221.

Brownlow, C.A. and E.G. Bolen (1994). Fish and macro-invertebrate diversity in first order black-water and alluvial streams in North Carolina. Journal of Freshwater Ecology 9(3): 261-269.

Das, S.M. (1989). Aquatic pollution and fisheries in India. In: Perspectives in Aquatic Ecology. (Edi: R.D. Khulbe). Papyrus Publishing House, New Delhi, pp. 43-49.

Day, F. (1878). The Fishes of India, being a Natural History of the Fishes known to inhabit the Seas and Freshwaters of India, Burma and Ceylon. Volumes 
I and II, Reprint. Today and Tomorrow's Book Agency, New Delhi.

Dhanze, R., I. Sharma and J. R. Dhanze (1998). Hydrobiology of the sub-temperate streams of Beas Drainage system with reference to fish faunal resource. Journal of Natcon 10(2): 133142.

Dubey, V.K., U.K. Sarkar, A. Pandey, R. Sani and W.S. Lakra (2012). The influence of habitat on the spatial variation in fish assemblage composition in an un-impacted tropical river of Ganga basin, India. Aquatic Ecology 46(2): 165-174.

Dudgeon, D. (1999). Tropical Asian Streams: Zoobenthos, Ecology and Conservation. Hong Kong University Press, Hong Kong.

Edds, D.R. (1993). Fish assemblage structure and environmental correlates in Nepal's Gandaki River. Copeia 1993(1): 48-60.

Edds, D.R., D.P. Gillette, T.M. Maskey and M. Mahato (2002). Hot-soda process paper mill effluent effects on fishes and macroinvertebrates in the Narayani River, Nepal. Journal of Freshwater Ecology 17(4): 543-554.

Esselman, P.C. and J.D. Allan (2010). Relative influence of catchment and reach-scale abiotic factors on freshwater fish communities in rivers of North-eastern Mesoamerica. Ecology of Freshwater Fish 19(3): 439-454.

Ferrow, W. and P.R. Badgami (1980). On the biology of the commercially important species of fish of the Pokhara Valley, Nepal. Journal of Institute of Science 3(1): 237-250.

Fialho, A.P., L.G. Oliviera, F.L. Tejrina-Garra and B. De Merona (2008). Fish-habitat relationship in a tropical river under anthropogenic influences. Hydrobiologia 598(1): 315-324.

FRC, Pokhara (1991-92). Annual Technical Report. Fisheries Research Center (FRC), Pokhara, Nepal.

Golterman, H.L., R.S. Clymo and M. Ohnstad (1978). Methods for Physical and Chemical Analysis of Freshwaters. $2^{\text {nd }}$ edition, IBP Hand Book No, 8. Blackwell Scientific Publishers,
Oxford.

Gubhaju, S.R. and K. Giri (2010). Study on distribution pattern of fishes and the socioeconomic condition of fisher community in Phewa Lake, Pokhara, Nepal. In: Abstracts of International Conference on Biodiversity, Livelihood and the Climate Change in the Himalayas. (Eds. P.K. Jha, K.K. Shrestha, R.P. Chaudhary, M.K. Chhetri, D.R. Bhuju, S. Rajbhandary, B.B. Shrestha and S. Devkota). Central Department of Botany, Tribhuvan University, Kathmandu, Nepal, pp. 136-137.

Gupta, B.K., U.K. Sarkar and S.K. Bhardwaj (2012).

Assessment of habitat quality with relation to fish assemblages in an impacted river of the Ganges basin, Northern India. The Environment 32(1): 35-47.

Hijmans, R.J. and J. Elith (2013). Species Distribution Modeling with R. Retrieved from http:/ / cran.rproject.org/web/packages/raster/vignettes/ Raster.pdf.

Jayram, K.C. (1999). The Freshwater Fishes of Indian Region. Narendra Publishing House, New Delhi.

John, A. and R.G. Dhewajoo (1989). Effect of Ecological Parameters on Fishes of Pokhara Valley.

A Report. Royal Nepal Academy of Science and Technology (RONAST), Kathmandu.

Lasso, C.A. (2001). Fishes of the Upper Rio Negro, Bolivian Amazon: Community composition and ecological and bio-geographical considerations. Interciencia 26(6): 236-243.

Li, J., L. Huang, L. Zhou, Y. Kano, T. Sato and T. Yahara (2012). Spatial and temporal variation of fish assemblages and their associations to habitat variables in a mountain stream of North Tiaoxi, River, China. Environmental Biology of Fishes 93(3): 403-417.

Nikolsky, G.V. (1963). The Ecology of Fishes. Academic Press, London.

Pease, A.A., G. Diaz, R. Rodiles-Hernandez and K.O. Winemiller (2012). Functional diversity and trait environment relationships of stream fish assemblages in a large tropical catchment. 
Freshwater Biology 57: 1060-1075.

Pielou, E.C. (1975). The Ecological Diversity. John Wiley and Sons, New York.

Pielou, E.C. (1977). Mathematical Ecology. John Wiley and Sons, New York.

Pokharel, K.K. (2006). Fisheries resources of river and streams in Pokhara Valley, Nepal: Urgent need of conservation and sustainable utilization. In: Proceedings of Fourth National Conference of Science and Technology, Volume I. Nepal Academy of Science and Technology (NAST), pp. 315-331.

R. Core Team (2015). R: A Language and Environment for Statistical Computing. R Foundation for Statistical Computing, Vienna, Austria. Retrieved from http:/ /www.R.project.org/.

Ricker, W.E. (1968). Introduction to methods for assessment of fish production in freshwaters. In: Methods for Assessment of Fish Production in Freshwaters. (Edi. W.E. Ricker). International Biological Programme (IBP) and Blackwell Scientific Publication, pp. 1-6.

Seber, G.A.F. and F.D. Lecren (1967). Estimatting population parameters from catches large relative to the population. Journal of Animal Ecology 36: 631-643.

Shannon, C.E. and W. Weiner (1963). The Mathematical Theory of Communication. University of Illinois, Urbana, Illinois.

Sharma, C.K. (1977). River Systems of Nepal. Ms. Sangeeta Sharma, Kathmandu.

Shrestha, J. (1981). Fishes of Nepal. Curriculum Development Cneter, Tribhuvan University, Kathmandu.

Shrestha, J., D.M. Singh and T.B. Saund (2009). Fish diversity of Tamor River and its major tributaries of Eastern Himalayan region of Nepal. Nepal Journal of Science and Technology 10: 219-223.

Shrestha, T.K. (2008). Ichthyology of Nepal. Himalayan Ecosphere, Kathmandu.
Shukla, P. and A. Singh (2013). Distribution and diversity of freshwater fishes in Aami River, Gorkhapur, India. Advances in Biological Research 7(2): 26-31.

Simpson, E.H. (1943). Measurement of diversity. Nature 163-188.

Sugihara, G. (1980). Mimimal community structure, an explanation of species abundance pattern. American Naturalist 116: 770-787.

Sumith, J.A., K.R. Munkittrick and N. Athukorale (2011). Fish assemblage structure of two contrasting stream catchments of the Mahaweli River basin in Sri Lanka: Hallmarks of human exploitation and implications for conservation. The Open Conservation Biology Journal 5: 25-44.

Tripathi, M.P. (1984-85). Ecology of Pokhara Valley. In: Nepal Nature's Paradise. (Edi: T.C. Majupuria). White Lotus Company, Bangkok, pp. $438-452$.

Trivedy, R.K. and P.K. Goel (1984). Chemical and Biological Methods for Water and Pollution Studies. Environmental Publications, Karad, India.

Williams, L.R., C.S. Toepfer and A.D. Martinez (1996). The relationship between fish assemblages and environmental gradients in an Oklahoma Prairie stream. Journal of Freshwater Ecology 11(4): 459-467.

Wu, J., J. Wang and W. Cao (2011). Fish assemblage structure in the Chishui River, a protected tributary of the Yangtze River. Knowledge Management and Aquatic Ecosystems 400(11): 1-14.

Yildrim, A., M. Arslan and M.A. Pegg (2008). Patterns of fish communities along a mountain river, The Upper Coruh River (Turkey). Polish Journal of Ecology 56(4): 731-736. 